\title{
Replacement of Soybean Meal with Lupin or Chickpea Seed Meal in Diets for Fattening Iberian Pigs Promotes a Healthier Ileal Microbiota Composition
}

\author{
Luis A. Rubio*, M. Jesús Peinado \\ Fisiología y Bioquímica de la Nutrición Animal (EEZ, CSIC), Granada, Spain \\ Email: uis.rubio@eez.csic.es
}

Received 6 May 2014; revised 1 June 2014; accepted 30 June 2014

Copyright (C) 2014 by authors and Scientific Research Publishing Inc. This work is licensed under the Creative Commons Attribution International License (CC BY). http://creativecommons.org/licenses/by/4.0/

c) (i) Open Access

\begin{abstract}
Five castrated male Iberian pigs $(100 \pm 2 \mathrm{~kg}$ b.w.) fitted with T-shaped ileal cannulas at the terminal ileum were used to determine the effects of legume feeding on intestinal microbiota composition. The diets were based on defatted soybean (Glycine max), lupin (Lupinus angustifolius) or chickpea (Cicer arietinum) seed meals and contained similar amounts of digestible energy (14.2 $\left.15.1 \mathrm{MJ} \cdot \mathrm{kg}^{-1}\right)$ and protein $\left(107 \mathrm{~g} \cdot \mathrm{kg}^{-1}\right)$. A hydrolyzed casein diet was used to determine the bacterial counts in pigs fed on a vegetable-free diet. The composition of the intestinal microbiota at the terminal ileum was analysed by $q-P C R$. Higher $(P<0.05)$ lactobacilli $\log _{10}$ number of copies was determined in the ileal contents of pigs fed on lupin- or chickpea-based diets with respect to those fed on the soybean-based diet. Bacteroides and the Clostridium coccoides/Eubacterium rectale group $\log _{10}$ number of copies was lower $(P<0.01)$ than that of soybean in the ileal contents of chickpea-fed pigs. Enterobacteria and the Escherichia/Shigella group $\log _{10}$ number of copies was lower $(P<0.01)$ than that of soybean in pigs fed on diets based on lupin or chickpea. The number of copies of the different bacterial groups in animals fed on the casein-based diet was lower $(P<$ 0.01 ) than that of soybean for lactobacilli and bacteroides, but was higher than that of soybean for bifidobacteria, enterobacteria and the Escherichia/Shigella group. This information suggests that lupin or chickpea feeding might induce a benefit in the microbiota composition of Iberian pigs in their final productive stages.
\end{abstract}

\section{Keywords}

Defatted Soybean, Lupin, Chickpea, Iberian Pig, Ileal Microbiota

\footnotetext{
"Corresponding author.
} 


\section{Introduction}

Surplus pig meat production and growing public concern on animal welfare and soil pollution problems have resulted in the encouragement of the production of native pig breeds such as the Iberian pig which are well adapted to local feed resources and provide high quality products [1] [2]. Iberian pig breeding is peculiar in that in order to achieve higher organoleptic quality, and its final fattening stage (from 100 to about $160 \mathrm{~kg}$ body weight) is carried out in free range conditions. During that period, pigs are fed basically on acorns and grass, which are the predominant feedstuffs available in the Mediterranean woodland prairies. In these conditions, the use of local feed resources is of paramount importance for the sustainability of the system. However, this regime has been shown to be lower in protein, and particularly in lysine, than that required by the pig [2]. As a consequence, other protein supplements such as legume seed meals, which are grown in the same areas where this breed is produced, might be used to equilibrate its diet and achieve better productive results, even though this practice might alter the final product quality [3] if used in the final fattening period in extensive conditions. Locally grown legume seed meals have traditionally been, and at present in some cases are, incorporated into formulas for Iberian pigs up to $100 \mathrm{~kg}$ body weight. In addition, cereals and legumes are ingredients among those legally authorized in Spain in the fattening period of Iberian pig production stages [4]. Therefore, it is important to determine not only the digestibility of nutrients in these feedstuffs, but also the potential effects on the intestinal physiology to establish their practical usefulness in Iberian pig dietary formulas. The amount of information available on the digestive physiology of the Iberian pig is scarce, particularly if compared to lean pig breeds.

Problems associated with intestinal disorders in different production stages are among those of greatest economic impact at present for the pig production industry, and it holds true not only for lean breeds but also for Iberian pig production systems, where costs derived from gastrointestinal disorders sometimes exceed market prices (Sánchez Romero Carvajal Jabugo S.A., personal communication). As a consequence, there is at present the need to look for alternatives that could enhance the natural defense mechanisms of animals and reduce the massive use of antibiotics. In pigs, the distal small intestine is known to harbor more than $10^{8}$ bacteria/g or ml of gut contents [5]. As a consequence, one way to improve productive parameters and health in the pig industry is to use specific feed additives and/or dietary raw materials able to modulate the gut microbiota which plays a critical role in maintaining host health [6]. One of the main putative effects of certain additives or feedstuffs might be the improved resistance to potentially pathogenic bacteria colonization and enhanced host mucosa immunity, thus resulting in a reduced pathogen load, an improved health status of the animals and a reduced risk of food-borne pathogens in foods [7].

Accordingly, the present work was designed to study the effects of legume feeding on ileal microbiota composition of Iberian pigs. Pigs in the final fattening period (aprox. $100 \mathrm{~kg}$ body weight) were used because it is the period when the animals are fed with the ingredients which naturally grow in the Mediterranean prairies, and could more easily benefit from vegetable local ingredients. Lupins (Lupinus angustifolius) and chickpeas (Cicer arietinum) were chosen in this work due to their low content in antinutritional factors, and to differences in the composition of their constituent carbohydrates [8] [9].

\section{Materials and Methods}

\subsection{Animals, Diets and Feeding Regime}

Male castrated pigs from the Iberian breed were purchased from Sanchez Romero Carvajal S.A. (Huelva, Spain). Five animals (100 $\pm 2 \mathrm{~kg}$ mean live b.w.) fitted with T-shaped ileal cannulas surgically implanted [10] about 15 $\mathrm{cm}$ anterior to the ileocecal junction were used. They were housed individually in $4 \mathrm{~m}^{2}$ pens in a temperature controlled $\left(20^{\circ} \mathrm{C} \pm 1^{\circ} \mathrm{C}\right)$ room and allowed to recover from surgery. Feed energy and protein composition were calculated according to ingredients values in [11], and given at about twice their calculated energy maintenance needs (MEm $=458 \mathrm{~kJ}$ per kg ${ }^{0.75}$ b.w.; NRC, [11]) and offered in two meals (at 9:00 a.m. and 18:00 p.m. respectively) of $1 \mathrm{~kg}$ each. Water was freely available from low pressure drinking nipples. The design was as previously described [8] [9]. The five animals were fed the same experimental diet for 7 day adaptation and 3 day collection periods. The sequence of feeding the experimental diets was soybean, lupin, chickpea and casein. Samples from the cannulas were taken from day 8 to 10 in plastic bags attached to them. The bags were withdrawn at time intervals $<30 \mathrm{~min}$ from 10:00 to 18:00 h. The bags were immediately frozen in liquid $\mathrm{N}$ and freeze-dried. Fistulated pigs remained in good condition throughout the whole experimental period, and digesta 
flowed through the cannulas without blockages. The diets (Table 1) were based in defatted soybean, lupin or chickpea seed meals as only protein sources, and contained similar amounts of digestible energy (14.2 - 15.1 $\left.\mathrm{MJ} \cdot \mathrm{kg}^{-1}\right)$ and protein $\left(107 \mathrm{~g} \cdot \mathrm{kg}^{-1}\right)$. A diet based in hydrolyzed casein was used to determine the bacterial counts in pigs fed on a vegetable-free diet. The diets were also supplemented with vitamins and minerals to meet requirements [11]. Defatted soybean (Glycine max) meal and commercial varieties of lupin (Lupinus angustifolius) and chickpea (Cicer arietinum) seeds were purchased locally. Hydrolyzed casein was from Sigma (Alcobendas, Madrid, Spain). All management and experimental procedures carried out in this study were done in strict accordance with the appropriate practices for management of experimental animals in Spain (Act no. 223/88 of 18 March 1988) and done by staff trained to carry out such procedures.

\section{2. q-PCR Analysis of Bacterial Groups}

Total DNA was isolated from freeze-dried intestinal samples of ileal mucosa (40 mg) using the QIAamp DNA stool kit (Qiagen, West Sussex, UK) by following manufacturer's instructions. In order to increase its effectiveness, the lysis temperature was increased to $95^{\circ} \mathrm{C}$ and an additional step with lysozyme $\left(10 \mathrm{mg} \cdot \mathrm{mL}^{-1}, 37^{\circ} \mathrm{C}, 30\right.$ min) incubation was added. Eluted DNA was treated with RNase and the DNA concentration and purity assessed spectrophotometrically $(260-280 \mathrm{~nm}$ ) by using a NanoDrop ND-100 Spectrophotometer (NanoDrop Technologies, Wilmington, DE, USA). Purified DNA samples were stored at $-20^{\circ} \mathrm{C}$ until use [12]. Bacterial $\log _{10}$ number of copies was determined in by using q-PCR. The $16 \mathrm{~S}$ rRNA gene-targeted primers and PCR conditions used in this study were as previously described [13].

\subsection{Statistical Analysis}

Individual pigs were considered the experimental unit. The experimental data were subjected to a Two-way Analysis of Variance as a randomized design with diet composition, period of feeding and experimental replicate (block) as factors using a computer software package (Minitab Statistical Software Package, Minitab, New York, NY). In this design, the effects due to period of feeding and the interaction diet composition $\times$ period of feeding were first checked, and found not significant in all cases. The effects due to diet composition were studied by pairwise comparisons using the Tukey multiple comparison test.

Table 1. Composition $\left(\mathrm{g} \cdot \mathrm{kg}^{-1}\right)$ of the diets.

\begin{tabular}{|c|c|c|c|c|}
\hline Diet $^{1}$ & Soybean & Lupin & Chickpea & Hydrolyzed casein \\
\hline Maize starch & 700 & 530 & 250 & 680 \\
\hline Oil (sunflower) & 30 & - & - & 30 \\
\hline Vit $+\operatorname{Min}^{2}$ & 3 & 3 & 3 & 3 \\
\hline Ca carbonate & 2.8 & 2.7 & 7.1 & 5 \\
\hline Ca diphosphate & 11.7 & 12.6 & 3.7 & 25 \\
\hline Cellulose & - & - & - & 30 \\
\hline Sucrose & - & - & - & 100 \\
\hline Sodium chloride & - & - & - & 5 \\
\hline Soybean meal $46 \%$ & 252.5 & - & - & - \\
\hline Lupin meal & - & 451.7 & - & - \\
\hline Chickpea meal & - & - & 736.2 & - \\
\hline Hydrolysed casein & - & - & - & 122 \\
\hline Digestible energy $\left(\mathrm{MJ} \cdot \mathrm{kg}^{-1}\right)$ & 14.8 & 14.2 & 14.2 & 15.1 \\
\hline Protein $^{3}$ & 107 & 107 & 107 & 73 \\
\hline
\end{tabular}

${ }^{1}$ For details see materials and methods. ${ }^{2}$ The mineral-vitamin mix contained (per kg): thiamin, 50 mg; piridoxine, 50 mg; riboflavin, 1000 mg; nicotinic acid, $7500 \mathrm{mg}$; calcium pantothenate, $5000 \mathrm{mg}$; folic acid, $100 \mathrm{mg}$; biotin, $100 \mathrm{mg}$; inositol, $8000 \mathrm{mg}$; retinol, $1125 \mathrm{mg}$; cholecalciferol, 750,000 IU; all-rac- $\alpha$-tocopherol, $1250 \mathrm{IU}$; menadione bisulfite, $500 \mathrm{mg}$; cyanocobalamin, $5 \mathrm{mg}$; folic acid, $5 \mathrm{mg}$; Mg, 5 g; Fe, 25 g; Zn, 40 g; I, 150 mg; Cu, 20 g; Co, 100 mg. ${ }^{3} \mathrm{~N}$ determined by Kjeldahl. Protein in diets calculated as $\mathrm{N} \times 5.5$ in legume-based diets [23], and $\mathrm{N} \times 6.25$ in the hydrolyzed casein diet. 


\section{Results and Discussion}

As shown in Table 2, higher $(P<0.01)$ lactobacilli $\log _{10}$ number of copies was determined in the ileal contents of pigs fed on lupin or chickpea-based diets with respect to those fed on the soybean-based diet. Bacteroides $\log _{10}$ number of copies was lower $(P<0.01)$ in ileal contents of chickpea-fed pigs. Enterobacteria and Escherichia/ Shigella $\log _{10}$ number of copies was lower $(P<0.01)$ than that of soybean in pigs fed on diets based on lupin or chickpea. The $\log _{10}$ number of copies of the Clostridium coccoides/Eubacterium rectale group was lower than that of soybean in pigs fed on the chickpea diet. Bifidobacteria and Clostridium leptum number of copies was not affected by the legume seed meal incorporated to the diet. The number of copies of the different bacterial groups analysed in the animals fed on the casein-based diet was lower $(P<0.01)$ than that of soybean for lactobacilli and bacteroides, while they were higher than that of soybean for bifidobacteria, enterobacteria and the Escherichia/Shigella group.

While information on the use of lupin seed meal for pigs is more abundant [14], works with chickpea meal are scarce in the literature, and even less has been reported in Iberian pig feeding. In a previous work by our group, it was concluded that true ileal nitrogen and amino acid digestibilities of lupin and chickpea meals are comparable to those of defatted soybean in Iberian pigs [7], and higher total amounts of lupin NSP and/or lupin and chickpea oligosaccharides were digested up to the terminal ileum compared to defatted soybean [9]. Also, previous works in rats and pigs [15]-[17] indicate that the main reason for the higher faecal $\mathrm{N}$ excretion found in legume fed animals is that intestinal, and particularly lower gut microflora, increases its growth at the expense of undigested carbohydrates coming from the small intestine and urea supplied mainly through the large intestinal wall. It is known that the digestibility and fermentation of legume carbohydrates (mainly starch, NSP and oligosaccharides) in the gut have both healthy and productive implications [18].

In normal conditions, the main role of the intestinal microbiota is to provide a barrier against the invasion of potentially harmful bacteria [18]. Accordingly, a lot of research has been devoted in recent decades to the study of the potential therapeutic and productive uses of dietary additives/supplements able to limit the growth of potentially harmful bacteria such as enterobacteria, clostridia and E. coli [6]. Lactobacilli and bifidobacteria are among the most studied species out of those with alleged probiotic effects. The mechanism by which those species may play a beneficial role is related to the production of specific antibiotics, but particularly acetic and lactic acids, which lower the $\mathrm{pH}$ of the intestinal contents make it less favorable for the growth of coliforms [6] [18]. Also, the C. coccoides/E. rectale cluster includes bacteria producing butyric acid, a metabolite seen to be beneficial for gut functionality in pigs through regulation of epithelial cell growth, induction, differentiation and apoptosis in the small intestine, increase of intestinal cell proliferation and improvement of digestive and absorptive capacities of the small intestine [18].

In the present work, higher $\log _{10}$ counts of lactobacilli, and lower enterobacteria and Escherichia/Shigella counts, were determined with respect to soybean and casein-fed pigs in the intestinal contents of pigs fed on either lupin or chickpea diets (Table 2). Previous work in rats [19] and broiler chickens [20] fed on purified lupin fractions indicated that the NSP fraction was mainly responsible for similar effects on intestinal microbiota composition. As already mentioned, lupin and chickpea meals were chosen for the experiments described here, among other reasons, because of the different chemical composition of their constituent carbohydrates. Thus,

Table 2. Bacterial $\log _{10}$ number of copies/mg of freeze-dried ileal contents in cannulated pigs fed on diets based in defatted soybean, lupin or chickpea seed meals as the only protein source.

\begin{tabular}{cccccc}
\hline Diet & Soybean & Lupin & Chickpea & Casein & Pooled SD \\
\hline Lactobacilli & $4.18^{\mathrm{a}}$ & $4.93^{\mathrm{b}}$ & $5.73^{\mathrm{c}}$ & $2.69^{\mathrm{d}}$ & 0.41 \\
Bifidobacteria & $2.36^{\mathrm{a}}$ & $2.61^{\mathrm{a}}$ & $2.46^{\mathrm{a}}$ & $3.52^{\mathrm{b}}$ & 0.56 \\
C. coccoides/E. rectale group & $4.10^{\mathrm{a}}$ & $3.76^{\mathrm{ab}}$ & $3.61^{\mathrm{b}}$ & $4.03^{\mathrm{a}}$ & 0.39 \\
C. leptum & 3.62 & 3.51 & 3.45 & 4.16 & 0.30 \\
Enterobacteria & $4.26^{\mathrm{a}}$ & $3.52^{\mathrm{ab}}$ & $2.82^{\mathrm{b}}$ & $6.92^{\mathrm{c}}$ & 0.77 \\
Escherichia/Shigella group & $4.36^{\mathrm{a}}$ & $3.63^{\mathrm{ab}}$ & $3.20^{\mathrm{b}}$ & $5.50^{\mathrm{c}}$ & 0.70 \\
Bacteroides & $5.96^{\mathrm{a}}$ & $5.81^{\mathrm{a}}$ & $4.74^{\mathrm{b}}$ & $3.90^{\mathrm{c}}$ & 0.58 \\
\hline
\end{tabular}

\footnotetext{
${ }^{\mathrm{a}, \mathrm{b}, \mathrm{c}}$ Means $(\mathrm{n}=5)$ in the same row with different superscript letters differ $(P<0.01)$.
} 
while the main carbohydrate fraction in chickpea meal is starch, lupin meal contains only very low amounts of it (405 and $16 \mathrm{~g} \cdot \mathrm{kg}^{-1}$, respectively), and the reverse situation occurs with respect to NSP contents (86 and 319 $\mathrm{g} \cdot \mathrm{kg}^{-1}$, respectively). These differences in NSP contents are mainly due to high concentrations of galactose, glucose and uronic acids in lupin meal compared with other legumes. Soybean concentrate NSP values (168 $\mathrm{g} \cdot \mathrm{kg}^{-1}$ ) were intermediate between lupin and chickpea meals [9]. Amounts of lupin NSP digested $\left(94.1 \mathrm{~g} \cdot \mathrm{kg}^{-1}\right.$ feed) within the small intestine were higher than those for soybean and chickpea, which were not different from each other (24.3 and $27.1 \mathrm{~g} \cdot \mathrm{kg}^{-1}$ feed, respectively). However, not only NSP sugars, but also oligosaccharides have been associated with prebiotic effects, as legumes are known to contain substantial amounts of these compounds. Higher proportions of total oligosaccharides in lupin and chickpea diets were also digested compared with the soybean diet within the small intestine $\left(10.4,21.7\right.$ and $23.7 \mathrm{~g} \cdot \mathrm{kg}^{-1}$ diet ingested for soybean, lupin and chickpea diets, respectively) [9]. Therefore, since only whole seed meals were fed in the present investigation, and if not $\alpha$-galactosides or NSP in separated diets, it is not possible from the results reported here to assign the effects on microbial growth to either NSP and/or $\alpha$-galactosides in lupin or chickpea meals. The increase in bifidobacteria $\log _{10}$ counts in pigs fed on the casein-based diet might be related to the bifidogenic effect of casein fractions [21], while the increase in enterobacteria and the Escherichia/Shigella group is probably related to the low amount of dietary fibre, as higher enterobacteria and coliforms counts have been previously found in pigs fed on low fibre diets [22].

\section{Conclusion}

It is concluded that, in addition to economic and legal considerations, lupin and/or chickpea meal feeding might induce a more protective intestinal microbiota composition of Iberian pigs in their final productive stages.

\section{Acknowledgments}

The authors are indebted to the Spanish Junta de Andalucía (project AGR395) for financial support. This research has been also partially supported by the FEDER and FSE funds from the European Union. MJP is a recipient of a JAE-predoc fellowship from CSIC.

\section{References}

[1] Rey, A.I. and Lopez-Bote, C. (2001) Effect of Dietary Copper and Vitamin E Supplementation, and Extensive Feeding with Acorn and Grass on Longissimus Muscle Composition and Susceptibility to Oxidation in Iberian Pigs. Journal of Animal Physiology and Animal Nutrition, 85, 281-292. http://dx.doi.org/10.1046/j.1439-0396.2001.00316.x

[2] Nieto, R., Rivera, M., García, M.A. and Aguilera, J.F. (2002) Amino Acids Availability and Energy Value of Acorn in the Iberian Pig. Livestock Production Science, 77, 227-239. http://dx.doi.org/10.1016/S0301-6226(02)00040-4

[3] Aparicio Macarro, J.B. (1992) La montanera y el cerdo Ibérico. In: El cerdo Ibérico, la naturaleza y la dehesa, Ministerio de Agricultura, Pesca y Alimentación, 169-187. [Free Land Feeding and the Iberian Pig. In: The Iberian Pig, the Environment and the woodland Prairie, Spanish Ministry of Agriculture, Fisheries and Food, 169-187.]

[4] Spanish Administration (2007) REAL DECRETO 1469/2007 por el que se aprueba la norma de calidad para la carne, el jamón, la paleta y la caña de lomo ibéricos. BOE No. 264. [Spanish Administration (2007) Royal Decree 1469/2007 for the Approval of the Quality Law for Iberian Pig Meat, Ham and Loin. BOE No. 264.]

[5] Gaskins, H.R. (2001) Intestinal Bacteria and Their Influence on Swine Growth. In: Lewis, A.J. and Southern, L.L., Eds., Swine Nutrition, 2nd Edition, Taylor and Francis Inc., Boca Roca, 585-608.

[6] Gaggìa, F., Mattarelli, P. and Biavati, B. (2010) Probiotics and Prebiotics in Animal Feeding for Safe Food Production. International Journal of Food Microbiology, 141, S15-S28. http://dx.doi.org/10.1016/j.ijfoodmicro.2010.02.031

[7] Williams, B.A., Verstegen, M.W.A. and Tamminga, S. (2001) Fermentation in the Large Intestine of Single-Stomached Animals and Its Relationship to Animal Health. Nutrition Research Reviews, 14, $207-227$. http://dx.doi.org/10.1079/NRR200127

[8] Rubio, L.A. (2005) Ileal Digestibility of Defatted Soybean, Lupin and Chickpea Meals in Cannulated Adult Iberian Pigs. I. Proteins. Journal of the Science of Food and Agriculture, 85, 1313-1321. http://dx.doi.org/10.1002/jsfa.1963

[9] Rubio, L.A., Pedrosa, M.M., Pérez, A., Cuadrado, C., Burbano, C. and Muzquiz, M. (2005) Ileal Digestibility of Defatted Soybean, Lupin and Chickpea Meals in Cannulated Adult Iberian Pigs. II. Fatty Acids and Carbohydrates. Journal of the Science of Food and Agriculture, 85, 1322-1328. http://dx.doi.org/10.1002/jsfa.1964

[10] Canibe, N. and Eggum, B.O. (1997) Digestibility of Dried and Toasted Peas in Pigs. 2. Ileal and Total Tract Digestibil- 
ities of Amino Acids, Protein and Other Nutrients. Animal Feed Science and Technology, 64, 311-325. http://dx.doi.org/10.1016/S0377-8401(96)01038-3

[11] National Research Council (1998) Nutrient Requirements of Swine. 10th Revised Edition, National Academy Press, Washington DC.

[12] Ruiz, R. and Rubio, L.A. (2009) Lyophyllization Improves the Extraction of PCR-Quality Community DNA from Pig Fecal Samples. Journal of the Science of Food and Agriculture, 89, 723-727. http://dx.doi.org/10.1002/jsfa.3465

[13] Rubio, L.A., Peinado, M.J., Ruiz, R., Suárez-Pereira, E., Ortiz Mellet, C. and García Fernández, J.M. (2014) A Di-D-Fructose Dianhydride-Enriched Caramel Modulates Pig Fecal Microbiota Composition. Advances in Microbiology, 4, 242-251. http://dx.doi.org/10.4236/aim.2014.45031

[14] Jezierny, D., Mosenthin, R. and Bauer, E. (2010) The Use of Grain Legumes as a Protein Source in Pig Nutrition: A Review. Animal Feed Science and Technology, 157, 111-128. http://dx.doi.org/10.1016/j.anifeedsci.2010.03.001

[15] Rubio, L.A. (2004) Carbohydrates Digestibility and Faecal N Excretion in Rats Fed Raw and Germinated Faba Bean-(Vicia faba) and Chickpea-(Cicer arietinum) Based Diets. British Journal of Nutrition, 90, 301-309. http://dx.doi.org/10.1079/BJN2003903

[16] Goodlad, J.S. and Mathers, J.C. (1990) Large Bowel Fermentation in Rats Given Diets Containing Raw Peas (Pisum sativum). British Journal of Nutrition, 64, 569-587. http://dx.doi.org/10.1079/BJN19900057

[17] Schulze, H., van Leeuwen, P., Verstegen, M.W.A., Huisman, J., Souffrant, W.B. and Ahrens, F. (1994) Effect of Level of Dietary Neutral Detergent Fibre on Ileal Apparent Digestibility and Ileal Nitrogen Losses in Pigs. Journal of Animal Science, 72, 2362-2368.

[18] Bindelle, J., Leterme, P. and Buldgen, A. (2008) Nutritional and Environmental Consequences of Dietary Fibre in Pig Nutrition: A Review. Biotechnology, Agronomy, Society and Environment, 12, 69-80.

[19] Rubio, L.A., Spencer, R., Grant, G and Pusztai, A. (1995) The Inclusion of Lupin (Lupinus angustifolius) Seed Meal or Its Fibre Residue in the Diet Reduces Escherichia coli Counts in Both Small and Large Intestines of the Rat. Microbial Ecology in Health and Disease, 8, 101-105. http://dx.doi.org/10.3109/08910609509140086

[20] Rubio, L.A., Brenes, A., Setien, I., Asunción, G., Durán, N. and Cutuli, M. (1998) Lactobacilli Counts in Crop, Ileum and Caecum of Growing Broiler Chickens Fed on Practical Diets Containing Whole or Dehulled Sweet Lupin (Lupinus angustifolius) Seed Meal. British Poultry Science, 39, 354-359. http://dx.doi.org/10.1080/00071669888890

[21] Tang, X., Tian, Q., Cheng, X., Li, N. and Mao, X.-Y. (2013) Bifidobacterial Growth-Promoting Effect of Yak Milk $\kappa$-Casein Hydrolysates Produced with Different Proteases. International Journal of Food Science and Technology, 48, 1682-1687. http://dx.doi.org/10.1111/ijfs.12138

[22] Hermes, R.G., Molist, F., Ywazaki, M., Nofrarías, M., Gomez de Segura, A., Gasa, J. and Pérez, J.F. (2009) Effect of Dietary Level of Protein and Fiber on the Productive Performance and Health Status of Piglets. Journal of Animal Science, 87, 3569-3577. http://dx.doi.org/10.2527/jas.2008-1241

[23] Mossé, J. (1990) Nitrogen to Protein Conversion Factor for Ten Cereals and Six Legumes or Oilseeds. A Reappraisal of Its Definition and Determination. Variation According to Species and to Seed Protein Content. Journal of the Science of Food and Agriculture, 38, 18-24. http://dx.doi.org/10.1021/jf00091a004 
Scientific Research Publishing (SCIRP) is one of the largest Open Access journal publishers. It is currently publishing more than 200 open access, online, peer-reviewed journals covering a wide range of academic disciplines. SCIRP serves the worldwide academic communities and contributes to the progress and application of science with its publication.

Other selected journals from SCIRP are listed as below. Submit your manuscript to us via either submit@scirp.org or Online Submission Portal.
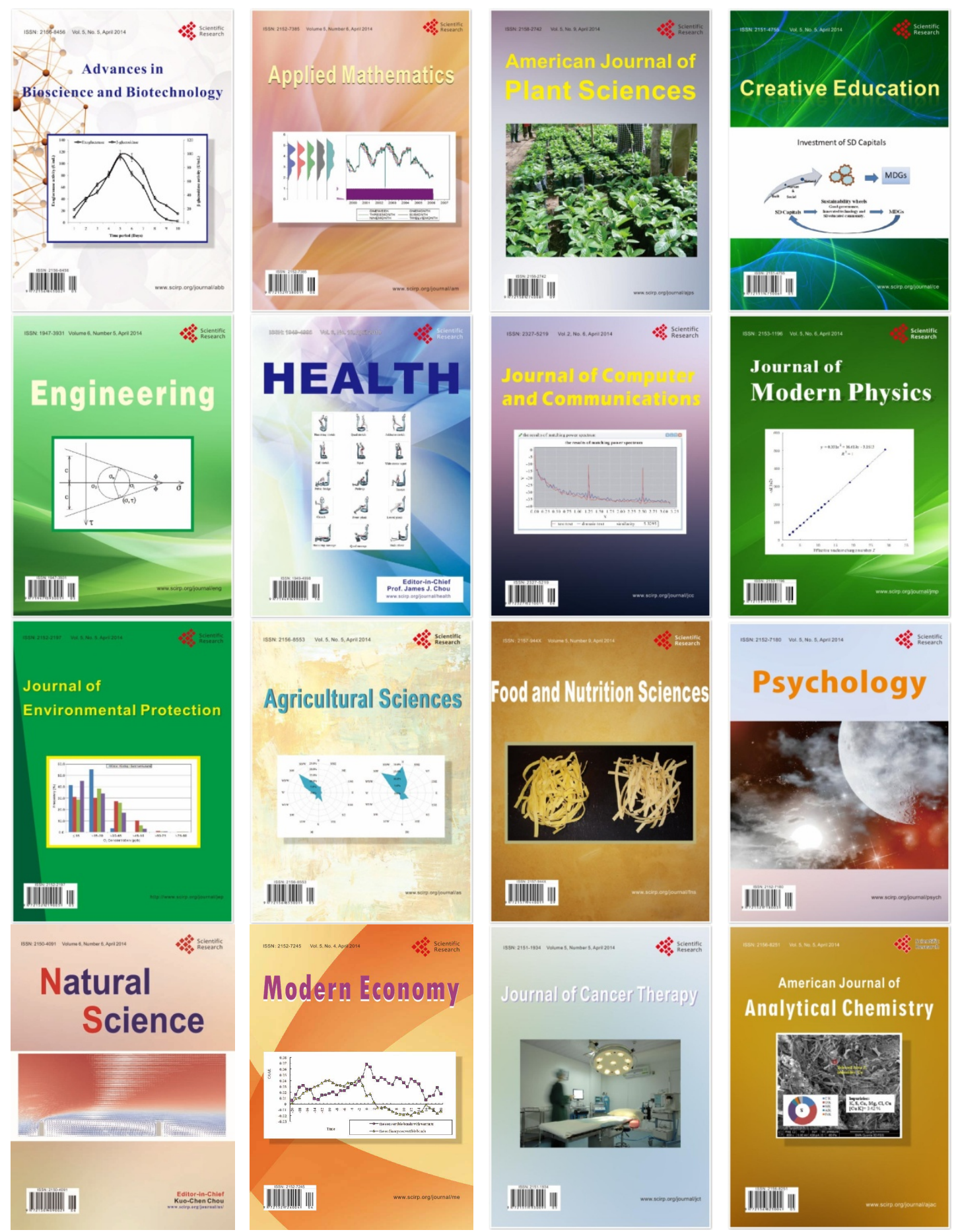